LAURA JANE HARDCASTLE

\title{
CAN'T SEE THE SCIENCE FOR THE SOLICITORS: JUDICIAL REVIEW OF SCIENTIFIC RESEARCH IN LIGHT OF NIWA'S CASE
}

Submitted for the LLB (Honours) Degree

Faculty of Law

Victoria University of Wellington

2013 


\section{Contents}

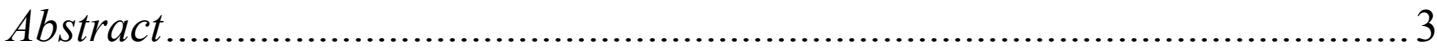

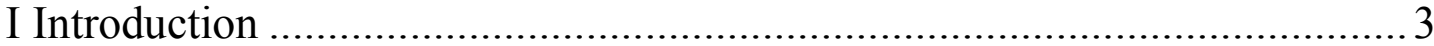

II Out of the Lab and into Litigation: NIWA's case ....................................... 4

A Availability and Standard of Judicial Review......................................................... 5

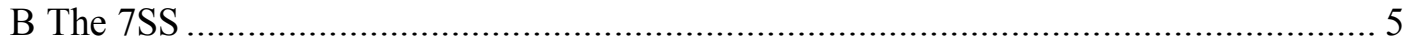

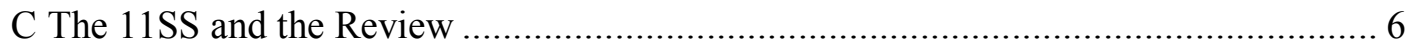

III Problems of 'publicness': why NIWA's decisions were within the Court's

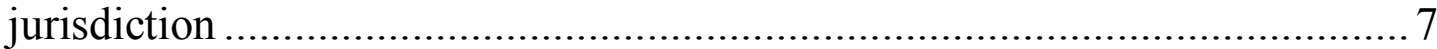

A Have individuals' rights been affected? ....................................................... 8

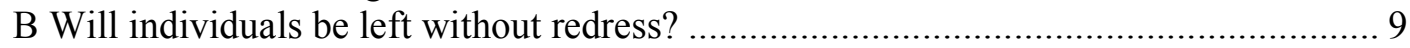

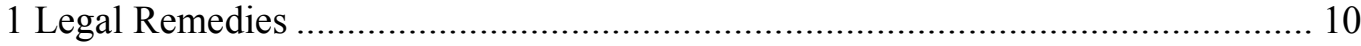

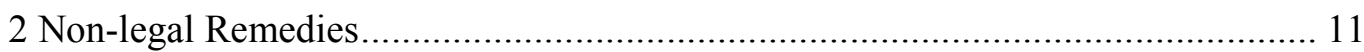

C Has a public decision-making power been exercised? ………….......................... 12

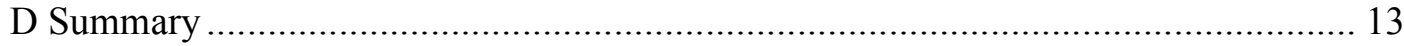

IV Judging justiciability: why NIWA's decisions should be declared non- or

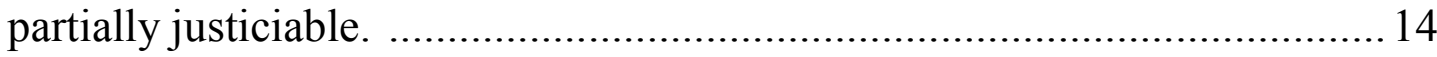

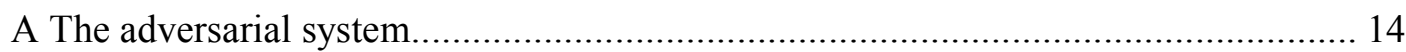

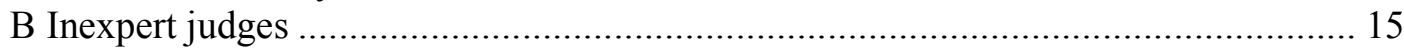

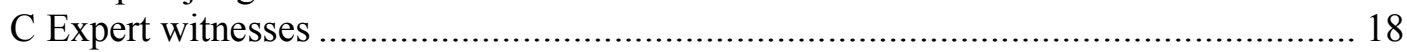

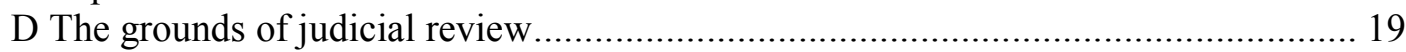

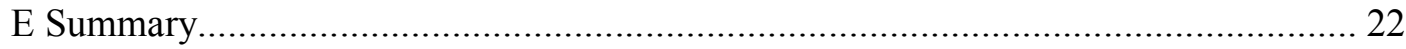

V Definitely deference: solutions to the problem of judicially reviewing

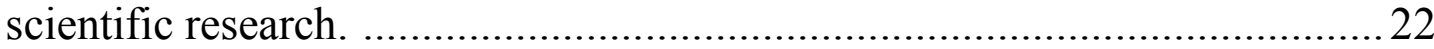

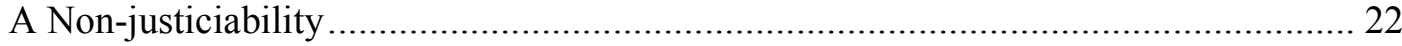

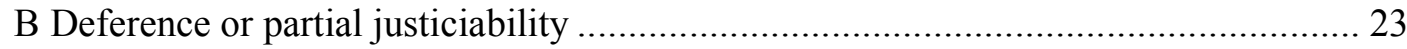

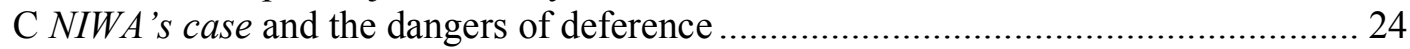

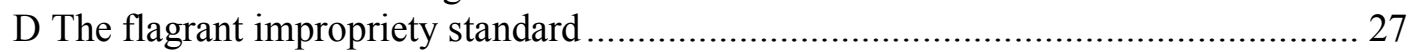

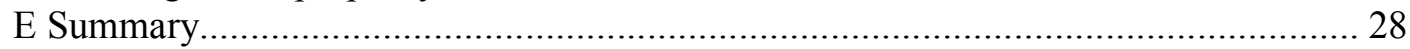

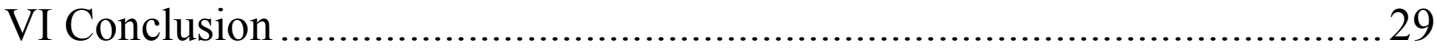

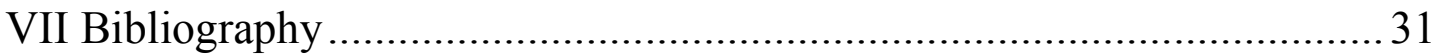

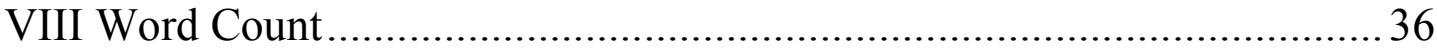




\section{Abstract}

The existence of climate change remains an unjustifiably vexed issue worldwide. In New Zealand Climate Science Education Trust v National Institute of Water and Atmospheric Research Ltd, sceptics' attempts to challenge NIWA's temperature records allowed the Court to extend its reach into the heart of the scientific research process. Whilst this paper supports Venning J's determination that NIWA's decisions were within the Court's jurisdiction for review, his finding that individuals might suffer harm as a result of them is shown to be unjustified. Furthermore, the Court's inherent unsuitability to addressing matters with high scientific contents, due to its adversarial nature and judges' lack of scientific training, supports a finding of non- or partial justiciability. Non-justiciability is here rejected for allowing scientists behaving fraudulently to escape rebuke. The standard of deference Venning J attempts to introduce is similarly flawed as it allows unwary judges to unintentionally judge matters of science. Concerns are also raised that research might stagnate if scientists must worry about judicial scrutiny of their work. Thus, a standard of flagrant impropriety, or "fraud, corruption or bad faith", is argued to be the ideal threshold for permitting judicial review of scientific research.

Key Words: judicial review, scientific research, NIWA, justiciability, deference

\section{Introduction}

In 2012, scientists nationwide celebrated Venning J's decision in New Zealand Climate Science Education Trust $v$ National Institute of Water and Atmospheric Research Ltd (NIWA's case). ${ }^{1}$ The case was brought by climate change sceptics questioning the methodology used by the National Institute of Water and Atmospheric Research (NIWA) to compile data indicating that New Zealand's temperature had risen over the last century. The New Zealand Climate Science Education Trust (the Trust) sought judicial review of NIWA's decision to publish the data; however, having dismissed much of the Trust's evidence, the judge found in NIWA's favour. This result, scientists believed, demonstrated judicial willingness to uphold scientific research processes, forcing "those wanting to challenge widely-agreed scientific findings to do so honestly and openly in scientific forums". 2 They were wrong. In reality, the High Court had ensured its own ability to

\footnotetext{
${ }^{1}$ New Zealand Climate Science Education Trust v National Institute of Water and Atmospheric Research Ltd [2012] 1 NZLR 75 [NIWA's case].

${ }^{2}$ James Renwick “Leading Climate Scientists Welcome Judge’s Decision” (press release, 7 September 2012).
} 
review research compiled by Crown Research Institutes (CRIs). ${ }^{3}$ A requirement that courts be "cautious" when interfering with specialist bodies' findings is all that now prevents judges from intervening in scientific research. ${ }^{4}$

In this paper, I argue that this is insufficient. Instead, CRIs' decisions should be reviewed only in cases of "fraud, corruption or bad faith." In Part III, I agree with Venning J that NIWA's decisions were public and thus within jurisdiction for judicial review. Despite exaggerating the decisions' impacts on individuals and the lack of alternative relief, the judge does not deserve criticism for considering NIWA's institutional characteristics. However, the unsuitability of court processes to addressing matters of science, as demonstrated in Part IV, cannot be ignored. Problems surrounding the adversarial system, inexpert judges and often-partisan expert witnesses make the Court ill-equipped to resolve scientific issues. In Part V, I examine two possible responses: non-justiciability and partial justiciability, otherwise known as deference. Non-justiciability is rejected for allowing scientists behaving fraudulently to escape scrutiny. However, Venning J's formulation of deference is insufficient to protect the research process's integrity. I instead advocate for review only in cases of flagrant impropriety.

\section{Out of the Lab and into Litigation: NIWA's case}

In 2012, the New Zealand Climate Science Education Trust (the Trust) sought judicial review of the National Institute of Water and Atmospheric Research (NIWA). NIWA is a Crown Research Institute (CRI) dedicated to environmental science, including atmospheric, climatic and marine disciplines. ${ }^{6}$ At issue were temperature records, collated by NIWA, indicating that New Zealand had warmed over the past century. The Trust's first complaint concerned NIWA's decision to publish the 7SS temperature series, which revealed $0.9^{\circ} \mathrm{C}$ warming between 1909 and 2009. ${ }^{7}$ The 7SS (seven-station series) takes data from seven locations nationwide, merging it to give a national average of the annual mean surface temperature. ${ }^{8}$ However, the raw data must be adjusted to account for regions'

\footnotetext{
${ }^{3}$ The Crown Research Institutes are AgResearch, Institute of Environmental Science Research, Institute of Geological and Nuclear Sciences, Landcare Research, NIWA, Plant and Food Research and Scion. Ministry of Business, Innovation \& Employment "Crown research institutes" (1 February 2013) <www.msi.govt.nz>. ${ }^{4}$ NIWA's case, above n 1 , at [41].

${ }^{5}$ Mercury Energy Ltd v Electricity Corporation of New Zealand Ltd [1994] 2 NZLR 385 at 392.

${ }^{6}$ NIWA "Our Science" <www.niwa.co.nz>.

${ }^{7}$ NIWA's case, above $\mathrm{n} 1$, at [4].

${ }^{8}$ The sites used are Auckland, Masterton, Wellington, Hokitika, Nelson, Lincoln and Dunedin. See NIWA

"Seven-station series temperature data"<www.niwa.co.nz>.
} 
differing climates as well as site-specific factors such as shelter from trees and movement of weather stations. ${ }^{9}$ The Trust objected to NIWA's method of adjustment, similarly criticising the eleven-station series (11SS) which corroborated the 7SS, and the review NIWA conducted after the Trust's initial complaint. ${ }^{10}$

\section{A Availability and Standard of Judicial Review}

The initial issue was whether judicial review was available. Venning $\mathrm{J}$ determined that it was, having considered NIWA's statutory origin, its obligation to undertake research benefitting New Zealand, and the retention of its shares by responsible ministers. ${ }^{11}$ The judge also reasoned that as NIWA's research may influence government policy, its actions may affect citizens' rights. ${ }^{12}$ Furthermore, unlike cases involving State-owned Enterprises (SOEs), plaintiffs could not seek private law remedies if judicial review were denied. ${ }^{13}$ Thus, Venning J concluded that judicial review was available as NIWA's functions are public, not commercial. ${ }^{14}$

In contemplating the appropriate standard of review, Venning $\mathrm{J}$ held that courts should be "cautious" when examining the work of specialists "acting within their own sphere of expertise". ${ }^{15}$ Thus, "less intensive review" is appropriate where the Court feels unable to decide between scientific opinions. ${ }^{16}$ The Trust therefore needed to demonstrate that the decision-making process was defective or "clearly wrong in principle or in law" before the Court would intervene. ${ }^{17}$

\section{B The 7SS}

Having dismissed much of the Trust's evidence as non-expert opinion, the judge rejected all complaints about the 7SS. ${ }^{18}$ These included that NIWA failed to consider "recognised scientific opinion", using methods to account for movement of monitoring sites described in a 1990 thesis, rather than the 1993 paper the Trust endorsed. ${ }^{19}$ This, the Trust claimed,

\footnotetext{
${ }^{9}$ Ibid.

${ }^{10}$ NIWA's case, above $\mathrm{n} 1$, at [11].

${ }^{11}$ At [20], [21] and [26]. See also Crown Research Institutes Act 1992, s 5.

${ }^{12}$ At [27].

13 At [34].

${ }^{14}$ At [32-33].

${ }^{15}$ At [36] and [41].

${ }^{16}$ At [44].

${ }^{17}$ At [48].

${ }^{18}$ At [49-54] and [116].

${ }^{19}$ At [56].
} 
breached NIWA's obligation to "pursue excellence", which the judge found to be enforceable, ${ }^{20}$ as well as constituting a failure to consider mandatory considerations, unreasonableness and a mistake of fact. ${ }^{21}$

Venning $\mathrm{J}$ is clear that, while he does not wish to interfere with scientific debates, the Court will determine factual disputes. ${ }^{22}$ Thus, he would not resolve the parties' conflict over whether the 1993 paper contained the definitive methodology for such calculations. ${ }^{23}$ This was in any case rendered irrelevant by the Court's determination that NIWA had effectively used the 1993 paper's approach. ${ }^{24}$ The judge further found that NIWA met its obligation to consider "accepted scientific practices and opinions". ${ }^{25}$ An argument that NIWA made a mistake of fact by not appreciating that the warming trend observed was due to the movement of weather stations to warmer sites was also dismissed as NIWA's contrary explanation was "credible and understandable". ${ }^{26}$

\section{The 11SS and the review}

Similar claims regarding the $11 \mathrm{SS}$ were dismissed. ${ }^{27}$ The judge found NIWA's evidence that it had neither deliberately chosen sites supporting a warming trend nor ignored gaps in the record "credible and reasonable". ${ }^{28}$ However, he reiterated that the Court would not resolve matters involving "different contestable scientific opinions". 29

The Trust's final target was NIWA's review, which used a different methodology to demonstrate the 7SS's validity. ${ }^{30}$ It argued that NIWA ignored recognised scientific opinion, utilising the same grounds of review as for the $7 \mathrm{SS} .{ }^{31}$ In rejecting them, the judge concluded that whether a particular methodology was open to NIWA, and was not unprecedented and unpublished, was a matter of scientific debate and not for the Court to resolve. ${ }^{32}$ Venning $\mathrm{J}$ also accepted that recalculating temperatures using different methods

\footnotetext{
${ }^{20}$ At [66] and [77].

${ }^{21}$ At [106], [116] and [114].

${ }^{22}$ See for example at [78] and [115].

${ }^{23}$ At [79-82].

${ }^{24}$ At [83] and [104].

${ }^{25}$ At [105].

${ }^{26}$ At [113].

27 At [138-139].

${ }^{28}$ At [120].

${ }^{29}$ At [137].

${ }^{30}$ At [180-184].

${ }^{31}$ At [145].

${ }^{32}$ At [151].
} 
but generating the same results strengthened the claim that the 7SS was robust. ${ }^{33}$ Arguments that NIWA should not have compared particular sites and that data was used from sites sheltered by trees or buildings or impacted by urban heat island effects (resulting from cities being warmer than surrounding countryside as buildings and concrete retain additional heat) were dismissed as issues of science. ${ }^{34}$

Thus, the Trust's arguments were rejected entirely. However, that they were even considered sets a precedent which should concern all associated with CRIs. Whilst the following parts support Venning J's determination that NIWA's decisions were within the Court's jurisdiction for judicial review, they also examine why his attempts at deference had the opposite effect and why review of scientific research should be severely restricted.

\section{Problems of 'publicness': why NIWA's decisions were within the Court's jurisdiction.}

In this part, I contend that whilst Venning $\mathrm{J}$ was right to conclude that the Court had jurisdiction to judicially review NIWA's decision, his reasoning contains unfounded assumptions. Whilst the terminology remains controversial, ${ }^{35}$ jurisdiction here refers to one of two facets of amenability to review. ${ }^{36}$ The second, justiciability, is addressed in Parts IV and $V .^{37}$ Jurisdiction requires that decisions be public in nature before judicial review is permitted. It is essentially a "value judgment" as to whether public law principles should apply. ${ }^{38}$ Jurisdiction and justiciability overlap significantly. Whilst impacts on individuals' rights and the existence of alternative remedies may relate to justiciability, they are here included under jurisdiction as Venning $\mathrm{J}$ considers them whilst discussing publicness. ${ }^{39}$ Thus, this part demonstrates that the judge was mistaken in finding that NIWA's decisions affected individuals' rights and that alternative remedies were not

\footnotetext{
33 At [157].

34 At [173].

${ }^{35}$ See for example, Chris Finn "The Justiciability of Administrative Decisions: A Redundant Concept?" 30 FLR 240 at 262-263 and B V Harris "Judicial Review, Justiciability and the Prerogative of Mercy" (2003) 63 CLJ 631 at 632-633.

${ }^{36}$ Chris Finn "The concept of 'justiciability' in administrative law" in Matthew Groves and H P Lee, Australian Administrative Law: Fundamentals, principles and doctrines (Cambridge University Press, Cambridge, 2007) 143 at 144-147 and Jenny Cassie and Dean Knight "The Scope of Judicial Review: Who and what may be reviewed" (paper presented to New Zealand Law Society Administrative Law Conference, August 2008) 63 at 63-64.

${ }^{37}$ Finn "The concept of justiciability", above n 36, at 144-147.

${ }^{38}$ Peter Cane Administrative Law ( $5^{\text {th }}$ ed, Oxford University Press, Oxford, 2011) at 16.

${ }^{39}$ They are similarly treated in $R v$ Panel on Take-overs and Mergers, ex parte Datafin plc [1987] 1 All ER 564.
} 
available. However, Venning J's overall conclusion that NIWA was amenable to review is correct. Criticism of his institutional approach is unfounded.

\section{A Have individuals' rights been affected?}

A key element of 'publicness' and thus jurisdiction is whether a decision affects private individuals' rights. I contend that NIWA's decisions did not. ${ }^{40}$ Venning J determined that NIWA's research "may be used in developing Government policy" and thus may "adversely affect...rights and liabilities". ${ }^{41}$ However, it would then be the Government's decision to act upon that research in a particular way, not NIWA's publishing it, which caused harm. NIWA does not even suggest what action, if any, the government should take. Harm resulting from NIWA's decision is "hypothetical [in] character" as the Government may not (and probably will not) act upon NIWA's findings. ${ }^{42}$ Furthermore, decisions would be taken in the wider scientific context. If the Government opted to combat climate change, it would do so based on an array of national and international scientific opinion, not because of a single temperature series.

Furthermore, Venning J's approach assumes that policy-makers are ignorant of the uncertainties associated with science, which may lead to one paper producing aberrant results. In reality, significant public policy literature exists on the part scientific uncertainties play in "wicked" (highly complex) problems. ${ }^{43}$ Further, while no statistics exist on public servants' scientific literacy, it is noteworthy that four ministries regularly encountering scientific challenges have at least one science graduate on their leadership teams, two at PhD level, in addition to various scientific advisors. ${ }^{44}$ Thus, policy-makers should know not to base important decisions on single pieces of questionable scientific

\footnotetext{
${ }^{40}$ Reckitt and Coleman (New Zealand) Ltd $v$ Pharmaceutical Management Agency Ltd [1997] NZAR 464 at 474, and Judicature Amendment Act 1972, s 3. For an example of a decision to publish affecting rights, see Royal Australasian College of Surgeons v Phipps [1998] 3 NZLR 1 at 10.

${ }^{41}$ NIWA's case, above $\mathrm{n} 1$, at [27].

${ }^{42}$ Peters v Davison [1999] 2 NZLR 164 at 188.

43 Jake Chapman, Charlie Edwards and Simon Hampson Connecting the Dots (Demos, London, 2009), Matthijs Hisschemöller and Rob Hoppe "Coping with Intractable Controversies: The Case for Problem Structuring in Policy Design and Analysis" (1996) 8 Knowledge and Policy 40 and Connie P Ozawa "Science and Intractable Conflict" (2006) 24 Conflict Resolution Quarterly 197.

${ }^{44}$ These being the Ministries of Health, Environment, Primary Industries and Business, Innovation and Employment. See Ministry of Health "Executive Leadership Team” (21 September 2012) $<$ www.health.govt.nz>; Ministry for the Environment "Leadership Team" (25 January 2013) $<$ www.mfe.govt.nz >; Ministry for Primary Industries "Senior Leadership Team" (25 July 2013) $<$ www.mpi.govt.nz>; and Ministry for Business, Innovation and Employment "Senior leadership" (30 January 2013) <www.mbie.govt.nz>.
} 
evidence. Should they do so, judicial review of the resultant policy decision to force a wider look at the available information would be appropriate.

Harm to individuals' reputations might also prompt review. ${ }^{45}$ Even mere opinion may be sufficiently damaging, if accompanied by "real practical consequences". 46 However, NIWA's decision to publish seems unlikely to harm even highly-polluting industries' reputations. First, the 7SS and its associated reports merely illustrate a warming trend; there is no reference to climate change, the greenhouse effect or carbon dioxide and thus no implied criticism of organisations potentially contributing to climate change. ${ }^{47}$ Second, attributing any harm to reputations to this particular report would be difficult. It would more likely result from the huge volume of scientific evidence of anthropogenic climate change worldwide. Even where a more direct connection between the research and businesses' activities exists, it remains arguable that reasonable members of the public understand that a single piece of research is not conclusive. Events such as "Glaciergate", where the Intergovernmental Panel on Climate Change mistakenly reported that all Himalayan glaciers would disappear 300 years too early, have shown that reputable institutions can make mistakes. ${ }^{48}$ This of course does not mean we should abandon all control of the scientific process to judges lacking scientific training.

\section{B Will individuals be left without redress?}

If individuals are to be harmed by a decision, courts will be reluctant to deprive them of redress; however, where other remedies are available, relief may be denied. ${ }^{49}$ Venning $\mathrm{J}$ expresses anxiety that, as private law actions against NIWA are unavailable, denying judicial review would leave plaintiffs without recourse to the courts. ${ }^{50}$ This concern is unfounded. Policy decisions made using NIWA's research remain reviewable. Furthermore, the policy stage is when individuals are affected and to postpone review until then is more consistent with international authority. Parties may also utilise non-legal methods.

\footnotetext{
${ }^{45}$ Peters $v$ Davison, above $\mathrm{n}$ 42, at 166.

${ }^{46}$ At 182 and 188.

${ }^{47}$ Global warming is mentioned but in reference to the findings of a particular article and not in reference to the temperature data at issue. NIWA Report on the Review of NIWA's 'Seven-Station' Temperature Series NIWA Information Series No. 78 (NIWA, Wellington, 2010).

${ }^{48}$ Malcolm Downden "Has climate change litigation become more difficult? [2010] 160 NLJ 171 at 171.

${ }^{49}$ Waitakere City Council v Waitemata Electricity Shareholders Society Inc [1996] 2 NZLR 735 at 747; Mercury Energy, above n 5, at 391 and McGechan on Procedure (Brookers, Wellington, 1995-) para JA4.03.

${ }^{50}$ NIWA's case, above $\mathrm{n} 1$, at [34].
} 


\section{Legal remedies}

As discussed above, Venning $\mathrm{J}$ finds that harm may be caused by government decisions made using NIWA's research. ${ }^{51}$ It is therefore contended that it is more appropriate to seek remedies at the policy stage. Alternatively, in the language of "ripeness for review", a concept prevalent in US literature, no "real and... imminent" problems exist until the Government acts; only then is judicial intervention appropriate. ${ }^{52}$

Belize Alliance of Conservation Non-Governmental Organizations $v$ The Department of the Environment and Belize Electric Company Ltd offers a prominent example of review occurring at the policy stage rather than once research is published. ${ }^{53}$ The Privy Council was primarily occupied with deficiencies in scientific reports on the planned location for a dam. These included glaring errors in the geological survey, which mistook sandstone for granite. ${ }^{54}$ However, it was the government's decision to build the dam that was under review; there were no separate proceedings reviewing the research.

The European Community Courts also review scientific research only at the regulatory stage. ${ }^{55}$ Expert bodies' scientific opinions are considered merely non-binding preparatory measures. ${ }^{56}$ They may thus be reviewed only indirectly once regulations based upon them are implemented. Furthermore, these opinions recommend courses of action and may not involve primary research, making them closer to policy decisions than the pure scientific research NIWA undertakes, yet they are not reviewable. ${ }^{57}$ However, clear illegality relating to these opinions generates a presumption that unlawfulness taints any consequent regulatory decisions. ${ }^{58}$ European courts will also only scrutinise procedural matters, not the underlying scientific evidence. ${ }^{59}$

\footnotetext{
${ }^{51}$ At [27].

${ }^{52}$ Kenneth Culp Davis "Ripeness of Governmental Action for Judicial Review” (1955) 68 Harv L Rev 1122 at 1122 .

${ }^{53}$ Belize Alliance of Conservation Non-Governmental Organizations $v$ The Department of the Environment and Belize Electric Company Ltd [2003] UKPC 47.

${ }^{54}$ At [38-48].

${ }^{55}$ See for example Case T-326/99 Nany Fern Olivieri v Commission and European Agency for the Evaluation of Medicinal Products [2003] ECR II-06053.

${ }^{56}$ Oliver Hartmann "The (Dis) Entanglement of Law and Science: Judicial Review of Science-Based Measures by EC Courts" (LLM Dissertation, University of Maastricht, 2008) at 10.

${ }^{57}$ At 8 .

${ }^{58}$ At 13 and 38.

${ }^{59}$ Joined Cases T-75/00, T-76/00, T-83/00, T-84/00, T-85/00, T132/00, T-137/00, T-141/00

Artegodan GmbH e.a. v Commission [2002] ECR 4945 at [197].
} 
By contrast, in the United States, "agency science" is reviewed, albeit with great deference. ${ }^{60}$ However, agency science differs significantly from NIWA's "pure research science". ${ }^{61}$ Its purpose is to fulfil legal obligations to allow implementation of policy decisions, leaving it open to abuse as government and interest groups heavily influence outcomes, timetables and funding. ${ }^{62}$ Former agency employees report that lawyers and policymakers deliberately manipulate and distort research outcomes. ${ }^{63}$ Thus, apparently scientific decisions are actually a science-policy hybrid. ${ }^{64}$ In contrast, CRIs, although Crown entities, are not in thrall to the Government, instead producing research for New Zealand's benefit, rather than for the ruling party. ${ }^{65}$

As the resulting policy decision may be reviewed, I contend that comprehensive judicial review of NIWA's decisions is unnecessary. Plaintiffs should not be allowed to challenge scientific research through both decisions to publish and the eventual policy decision. This would not only waste court time and resources, it undermines the finality of the Court's ruling. Arguably, it is more efficient to address problems with research before policy decisions are taken to avoid the same issue arising regarding multiple regulations. However, this presupposes any policy decision will be made based upon that research alone.

\section{Non-legal remedies}

Plaintiffs might also pursue non-legal options, such as publishing papers rebutting NIWA's research in well-respected journals. The principal control on scientific research comes after publication, when other scientists may scrutinise results and publish dissenting papers. While peer review attempts to ensure only quality research is published, it is not infallible. ${ }^{66}$ Less robust findings might not appear in major journals, but still be accepted by lesser known publications. ${ }^{67}$ Some peer reviewers may also favour particular

\footnotetext{
${ }^{60}$ Sara A Clark “Taking a Hard Look at Agency Science: Can the Courts Ever Succeed?” (2009) 36 Ecology LQ 317 at 326.

${ }^{61}$ Emily Hammond Meazell "Super Deference, the Science Obsession and Judicial Review as Translation of Agency Science” (2009) 109 Michigan Law Review 733 at 735 and 743.

${ }^{62}$ At 743 and 747.

${ }^{63}$ E Donald Elliott, Alan Charles Raul, Richard J Pierce Jr, Thomas O McGarity \& Wendy E Wagner "Science, Agencies, and the Courts: Is Three a Crowd?" (2001) 31 ELR 10125 at 10127.

${ }^{64}$ Hammond Meazell "Super Deference", above n 61, at 744-745.

${ }^{65}$ Crown Research Institutes Act, s 5.

${ }^{66}$ Patrick A Fuller "How Peer Review of Agency Science Can Help Rulemaking: Enhancing Judicial Deference at the Frontiers of Knowledge" (2007) 75 Geo Wash L Rev 931 at 956-957.

${ }^{67}$ Holly Doremus "The Purposes, Effects and Future of the Endangered Species Act's Best Available Science Mandate” (2004) 34 Envtl L 397 at 411.
} 
methodologies or results. ${ }^{68}$ Thus, papers will only gain reputability if other scientists support their conclusions and can repeat their results. ${ }^{69}$ If NIWA's results cannot withstand such scrutiny, the scientific community will quickly abandon them. This may take time, but as demonstrated above, organisations are unlikely to suffer harm in the interim. Even the Trust's own expert witness acknowledged that publishing a dissenting paper is the correct approach. ${ }^{70}$ This is more likely to advance the Trust's cause than court action as most people understand that judges are not scientists. The ability to resolve issues through non-legal methods has previously contributed to courts refusing judicial review, and arguably should have influenced Venning $\mathrm{J}^{71}$

\section{Has a public decision-making power been exercised?}

Determining whether NIWA has exercised a public decision-making power is problematic as, while the above suggests that its decisions had no "real practical" public consequences, NIWA is undoubtedly a public body. ${ }^{72}$ Cases examining a decision's 'publicness' may be categorised as institutional, which examine whether the responsible institution is a public body, or functional, which focus on the decision itself. ${ }^{73}$ Venning $\mathrm{J}$ employs the former approach, highlighting NIWA's establishment under the CRI Act, which dictates that research "be undertaken for the benefit of New Zealand". ${ }^{74}$ Further, he notes its public funding and accountability to a responsible minister. ${ }^{75}$

Ferrere criticises Venning J's institutional approach, arguing that the focus should have been on the nature of the decision. ${ }^{76}$ Indeed, since $R v$ Panel on Take-overs and Mergers, ex parte Datafin (Datafin), New Zealand has seen a trend towards an increasingly functional approach. ${ }^{77}$ Private institutions exercising public powers are now reviewable, whilst statutory recognition does not guarantee that all an organisation's functions will be scrutinised. ${ }^{78}$ However, there is a fundamental difference between individual researchers

\footnotetext{
${ }^{68}$ Fuller, above n 66, at 957.

${ }^{69}$ Doremus, above $\mathrm{n} 67$, at 411.

${ }^{70}$ NIWA's case, above $\mathrm{n} 1$, at [81].

${ }^{71}$ Cowl v Plymouth City Council [2002] 1 W.L.R. 803 at [25].

${ }^{72}$ Peters $v$ Davison, above n 42, at 188.

${ }^{73}$ Cassie and Knight, above n 36, at 66.

${ }^{74}$ NIWA's case, above $\mathrm{n} 1$, at [21] and [33].

${ }^{75}$ At [26].

${ }^{76}$ Marcelo Rodriguez Ferrere "Judicial review of scientific findings" [2012] NZLJ 380 at 381.

${ }^{77}$ Datafin, above n 39, at 569.

${ }^{78}$ Finnigan v New Zealand Rugby Football Union Inc (No 2) [1985] 2 NZLR 181 at 186 and Auckland Electric Power Board v Electricity Corporation of New Zealand CA 45/93, 8 September 1993 at 15.
} 
making false claims and publicly-funded CRIs doing so. Prominent later cases have acknowledged this, with courts adopting a combined institutional/functional, or contextually functional, approach. ${ }^{79}$ Even the Court in Datafin does not completely ignore institutional factors. ${ }^{80}$ Thus, Venning J was right to consider NIWA's position as a public institution.

Here, a contextually functional approach would acknowledge the improbability of NIWA's decisions having "important public consequences". 81 Furthermore, since anyone can publish virtually anything in today's technological world, it is difficult to consider publishing a public function. ${ }^{82}$ However, courts have reviewed decisions to publish reports based on inaccurate content. ${ }^{83}$ More importantly, NIWA's position as a CRI and use of public funds demand the application of the more stringent public law norms if they are being abused. Venning $\mathrm{J}$ was thus justified in determining that NIWA's decisions were public and within the Court's jurisdiction for judicial review.

\section{Summary}

Ultimately, there is no right answer as to whether NIWA's decisions are public or not as 'publicness' is not "like redness - a characteristic that can simply be observed." ${ }^{84}$ The lack of harm to individuals and availability of other remedies do not conclusively exclude the Court's jurisdiction. ${ }^{85}$ The trend since Datafin has been towards a contextually functional, not merely a functional, approach. Venning $\mathrm{J}$ was thus justified in considering NIWA's public attributes and concluding that its decisions were within jurisdiction. However, this does not mean that the contrary arguments explored above should be disregarded. Instead, these lend support to the arguments for non- or partial justiciability traversed in Part IV, and ultimately to my conclusion that review should be limited to cases of flagrant impropriety.

\footnotetext{
${ }^{79}$ Mercury Energy, above n 5 and Lab Tests Auckland Ltd v Auckland District Health Board [2008] NZCA 385. For discussion, see Cassie and Knight, above n 36, at 66.

${ }^{80}$ Datafin, above n 39, at 574.

${ }^{81}$ Royal Australasian College of Surgeons, above n 40, at 11.

${ }^{82}$ Cane, above n 38, at 271-272.

${ }^{83}$ See for example, Agrotain International LLC v Fertiliser Quality Council Inc HC Wellington CIV 2009485-1855, 17 December 2009.

${ }^{84}$ Cane, above n 38, at 17. Cassie and Knight, above n 36, at 65-66.

${ }^{85} R$ v Somerset County Council ex p Dixon [1997] COD 323.
} 


\section{Judging justiciability: why NIWA's decisions should be declared non- or partially justiciable.}

The "[un]suitability of the Court's personnel and processes" to resolving a particular dispute is key to determining justiciability ${ }^{86}$ However, justiciability, unlike jurisdiction, is part of a spectrum of responses the Court might employ, from non-justiciability (not examining the issue at all) to partial or secondary justiciability (which involves deference to the decision-maker) through the ordinary standard for review and on to hard-look review (where the Court more intensively scrutinises decisions). In this part, I traverse the arguments for review of scientific research falling on the non- and partial justiciability side of the spectrum. Issues highlighted include problems with the adversarial system, particularly in relation to polycentric decisions. Judges lacking scientific knowledge may struggle with decisions regarding research whilst expert witnesses may not represent mainstream scientific views. Furthermore, plaintiffs are unlikely to be disadvantaged if deprived of the full suite of judicial review grounds by either non- or partial justiciability, as many are problematic in their application to scientific research.

\section{A The adversarial system}

The adversarial system sees advocates relentlessly supporting their party to ensure that both sides' best arguments are considered. This contrasts strongly with the scientific approach of posing a hypothesis to see if the academic community can disprove it. ${ }^{87}$ Both methods have adapted to meet different objectives. Whilst science is the dispassionate search for truth, the law also seeks fairness. ${ }^{88}$

A clear example of the conflict between scientific and adversarial methods, although not court-based, is the climate change debate. The scientific community has long agreed that anthropogenic climate change is occurring, having rigorously tested this hypothesis. The only disagreements concern the precise magnitude of change, whether 'tipping points' exist and the sensitivity of the Earth system to changes in greenhouse gas concentrations. ${ }^{89}$

\footnotetext{
${ }^{86}$ Harris, above n 35, at 640 .

${ }^{87}$ Kristin Carden "Bridging the Divide: the Role of Science in Species Conservation Law" (2006) 30 Harv Envtl L Rev 165 at 171-172.

${ }^{88}$ Emily Hammond Meazell "Scientific Avoidance: Toward More Principled Judicial Review of Legislative Science" (2009) 84 Indiana Law Journal 240 at 250.

${ }^{89}$ See for example Greg O'Hare "Reviewing the Uncertainties in Climate Change Science" (2001) 32 Area 357 at 362 and 364.
} 
By contrast, the public have witnessed a war of attrition between ardent believers and disbelievers in climate change. In adversarial fashion, both sides cling to their convictions, raising any and all evidence, however dubious. ${ }^{90}$ This macro-scale example exposes the dangers of trying to resolve scientific issues using adversarial methods.

The adversarial system is also criticised for failing to adequately address polycentric decisions, those containing many intermingling and interacting factors which vary over time. ${ }^{91}$ These are not easily resolved into a two-sided issue as the Court process demands. ${ }^{92}$ Thus, it is doubtful whether polycentric decisions belong in court at all. Some authors counter that courts decide complex matters frequently. However, just because a question is complex does not mean it is polycentric. For example, considerable highly technical information might be needed to establish that a scientist acted fraudulently when conducting research; however, this remains a two-sided issue. By contrast, selecting a methodology requires consideration not only of existing scientific opinion, but also data that may contain subsets which would work better with different methodologies. Other factors such as required corrections and margins of error are then affected by methodology decisions and, in turn, impact the strength of final conclusions. Thus, such decisions are comparable to a spider's web, with multiple nodes affected if one strand is moved. ${ }^{93}$

\section{B Inexpert judges}

Furthermore, studies from the United States in light of Daubert $v$ Merrell Dow Pharmaceuticals Inc suggest that judges, a key component of the adversarial system, have difficulty understanding scientific matters. There is as yet no evidence to suggest a different result would be obtained in New Zealand.

In Daubert, the US Supreme Court gave itself responsibility for judging the credibility of scientific studies. ${ }^{94}$ Judges were charged with eliminating 'junk science' from the courtroom to prevent it from influencing juries. Rather than relying on experts with impressive credentials, judges must examine criteria such as falsifiability, peer review,

\footnotetext{
${ }^{90}$ For further discussion, see Graham Knight and Josh Greenberg "Talk of the Enemy: Adversarial Framing and Climate Change Discourse" (2011) 10 Social Movement Studies: Journal of Social, Cultural and Political Protest 323.

${ }^{91}$ Cane, above n 38, at 274.

92 At 275.

${ }^{93}$ Lon Fuller "The Forms and Limits of Adjudication" (1978) 92 Harvard Law Review 353 at 395 cited in Finn "The concept of justiciability", above n 36, at 146.

${ }^{94}$ Daubert v Merrell Dow Pharmaceuticals Inc [1993] US SC 92.
} 
error rates and whether the particular evidence is generally accepted by the scientific community. ${ }^{95}$ However, commentators have argued that judicial understanding of science is insufficient to perform this function, despite efforts to better train judges in dealing with scientific information through conferences and courses. ${ }^{96}$ Others have questioned whether it is fair to force judges to make decisions they are not trained for, with some finding the experience "uncomfortable and daunting". 97

Education within an adversarial system may cause judges to understand crucial concepts, such as uncertainty, very differently from scientists. The scientific method demands careful collection of data and integral to this process is recognising and accounting for uncertainty, with results always accompanied by confidence intervals. Judges by contrast seek "clear decisions [from] uncertain principles" so often favour 'bright-line' approaches, creating a threshold that evidence must meet to sustain a case. ${ }^{98}$ An example is the US approach to epidemiological evidence involving the increased risk of a particular condition developing in individuals exposed to certain factors. Multiple courts held that to find causation between the factor and condition, the risk to an average person must have doubled. $^{99}$ This leaves particularly susceptible plaintiffs unprotected. ${ }^{100}$ Whilst not a judicial review case, this example shows that even senior judges may inappropriately fuse legal and scientific concepts.

Essentially, a language barrier exists between judges and scientists, which is unsurprising given that 96 per cent of 400 judges surveyed in the US lacked general scientific training. ${ }^{101}$ Only four per cent properly understood error rates, whilst only six per cent understood falsifiability, worrying statistics given that these are fundamental scientific concepts. ${ }^{102}$ Judges also failed to accurately interpret statistical information, a problem also

\footnotetext{
${ }^{95}$ At 594.

${ }^{96}$ Edward K Cheng "Independent Judicial Research in the Daubert Age" (2007) 56 Duke Law Journal 1263 at 1273 .

${ }^{97}$ Andrew Jurs "Judicial Analysis of Complex \& Cutting-edge Science in the Daubert Era: Epidemiologic Risk Assessment as a Test Case for Reform Strategies” (2009) 42 Conn L Rev 49 at 55.

${ }^{98}$ Jurs, above n 97, at 51 and 57.

${ }^{99}$ Hall v Baxter Healthcare Corporation, 1996 WL 73063 and Allison v. McGhan Medical Corporation, 184 F.3d 1300, 1316 (11th Cir. 1999) as discussed in Jurs, above n 97.

100 Jurs, above n 97, at 58-59.

${ }^{101}$ Sophia I Gatowski, Shirley A Dobbin, James T Richardson, Gerald P Ginsburg, Mara L Marino and Veronica Dahir “Asking the Gatekeepers: A National Survey of Judges on Judging Expert Evidence in a Post-Daubert World" (2001) 25 Law and Human Behaviour 433 at 442.

${ }^{102}$ At 444 and 447.
} 
experienced in the New Zealand courts. ${ }^{103}$ Indeed, one argument raised in support of judicial review is that judges' written reasoning shows scientists how generalists perceive their evidence, as well as communicating it to the public. ${ }^{104}$ However, such an opinion could be obtained more cheaply and quickly through means other than litigation.

Undoubtedly, judges regularly consider complex scientific matters, such as those regarding forensic evidence in criminal trials. ${ }^{105}$ However, this does not justify ignoring the poor scientific literacy illustrated above. It is perhaps better to question whether currently judges are sufficiently equipped to determine the reliability of forensic evidence. Indeed, some surveys suggest that judicial understanding of concepts key to evaluating the usefulness of forensic analyses is also worryingly poor. ${ }^{106}$

It has been suggested that judges educate themselves before particular cases. Whilst this may undermine the adversarial system by encouraging judges to be more inquisitorial, whether this is considered positive or negative may depend on perspective. ${ }^{107}$ Of $136 \mathrm{US}$ judges surveyed, 21 per cent reportedly thought it very desirable to read additional peerreviewed articles, whilst 25 per cent considered it very undesirable. Such supplementary study is already banned in several US states, illustrating the tension over the appropriateness of judicial research into anything besides the law. ${ }^{108}$ Other problems include time constraints given judges' caseload, and ensuring the resources considered are of good quality. ${ }^{109}$ Further, inconsistencies may arise if some judges undertake additional research and others do not. ${ }^{110}$

Alternatively, specialist courts might be created to decide cases with high science contents. ${ }^{111}$ Such courts already exist for family, employment and environmental cases, with points of law appealable to the High Court and Court of Appeal. Specialist judges might better distinguish issues they may determine from scientific matters to be avoided. ${ }^{112}$

\footnotetext{
${ }^{103}$ Jurs, above n 97, at 73-74; Dean R Knight "Dunne v Canwest TVWorks Ltd: Enhancing or Undermining the Democratic and Constitutional Balance?" (2005) 21 NZULR 712 at 720-721.

${ }^{104}$ Hammond Meazell "Super Deference", above n 61, at 738.

${ }^{105}$ Elliott, Raul, Pierce, McGarity and Wagner, above n 63, at 10135.

${ }^{106}$ See for example Jan de Keijser and Henk Elffers "Understanding of forensic expert reports by judges, defense lawyers and forensic professionals" (2010) 18 Psychology, Crime \& Law 191.

${ }^{107}$ Cheng, above n 96, at 1275 and 1280.

${ }^{108}$ At $1275-1276$ and 1279.

${ }^{109}$ Elliott, Raul, Pierce, McGarity and Wagner, above n 63, at 10135.

${ }^{110}$ Cheng, above n 96, at 1308.

111 Jurs, above n 97, at 94-96.

112 At 94.
} 
However, cost is likely to be prohibitive, especially as difficult cases are infrequent. Furthermore, a Court whose primary purpose is to decide what it should not itself decide seems wasteful of resources. Thus, issues of judges' lack of scientific expertise must be addressed through other means, such as justiciability.

\section{Expert witnesses}

Expert witnesses should help remedy the deficiencies in judges' scientific knowledge. Expert witnesses are those with "specialised knowledge or skill based on training, study or experience". ${ }^{113}$ Their role is to assist the Court in understanding evidence or reach a decision of fact. ${ }^{114}$ However, it is questionable whether they are effective, given that a survey of lawyers found that many do not understand their own expert's testimony. ${ }^{115}$ It is unlikely judges fare any better, particularly as judicial review cases generally involve only written testimony. ${ }^{116}$

Such experts' overriding duty is to impartially assist the Court; however, their testimony may exhibit unconscious and selection biases. ${ }^{117}$ Unconscious bias refers to expert witnesses inadvertently aligning themselves with their client, in reaction to the adversarial system's competitive nature. ${ }^{118}$ Indeed, judges have criticised expert witnesses for precisely this. ${ }^{119}$ Selection bias is also problematic, as counsel hire experts not representative of mainstream scientific opinion, purely because they support their client's case. ${ }^{120}$ Thus, scientists with unconventional views are perceived to garner unjustified prominence in the courtroom. ${ }^{121}$ This may give decision-makers the impression that the debate amongst experts is heated when in fact one side has overwhelming support. ${ }^{122}$

Such bias might be overcome by utilising independent experts. Judges sitting alone might increasingly use their discretion to appoint independent experts to inquire into questions of

\footnotetext{
${ }^{113}$ Evidence Act 2006, s 4.

${ }^{114}$ Evidence Act 2006, s 25.

${ }^{115}$ Emily Henderson and Fred Seymour Expert Witnesses Under Examination in the New Zealand Criminal and Family Courts (New Zealand Law Foundation, Auckland, 2013) at 118-119.

${ }^{116}$ Philip A Joseph Constitutional \& administrative law in New Zealand ( $3^{\text {rd }} \mathrm{ed}$, Thomson Brookers, Wellington, 2007) at 881-882.

${ }^{117} R$ v Carter (2005) 22 CRNZ 476 at [47]; David E Bernstein "Expert Witnesses, Adversarial Bias, and the (Partial) Failure of the Daubert Revolution" [2008] 93 Iowa Law Review 101 at 104.

${ }_{118}$ Bernstein, above n 117, at 106.

${ }^{119}$ Vernon v Bosley (No 2) [1997] 1 All ER 614 (CA) at 647.

${ }^{120}$ Bernstein, above $\mathrm{n} 117$, at 106.

121 Jurs, above n 97, at 79; Henderson and Seymour, above n 115, at 89.

122 Bernstein, above n 117, at 106
} 
fact or opinion outside of the judge's expertise. ${ }^{123}$ Alternatively, the ability to appoint lay members to assist in understanding expert evidence could be extended to trials involving high scientific content. Lay members are currently permitted only in certain commercial, human rights and property matters. ${ }^{124}$

Even a court-appointed expert's opinion may not reflect the mainstream scientific position. ${ }^{125}$ A panel of experts would give a more nuanced view of any debate, although the generalist judge must make the final decision. Furthermore, judges supported by a panel of experts may feel confident ruling on increasingly scientific matters rather than restricting themselves to law and facts. There would also be practical constraints such as timing and cost when endeavouring to appoint such a panel and little research exists on the effectiveness of independent experts.

\section{$D$ The grounds of judicial review}

Furthermore, even if scientific research were declared non- or partially justiciable, plaintiffs will suffer little hardship as cases like NIWA's fit poorly into the grounds of judicial review. The Court is not restricted to examining the three traditional grounds of illegality, procedural impropriety and irrationality. ${ }^{126}$ However, many sub-grounds will be satisfied in such limited circumstances as to be virtually useless to plaintiffs. Scientific research seems very unlikely to encounter errors of law, for example. Others, such as error of fact, relevancy, bias and irrationality may be problematic in their application.

A claim of procedural impropriety, for example, appears unlikely to succeed in cases like NIWA's. Many organisations making decisions based on scientific information have consultation processes dictated by statute and it is entirely proper that the Court should enforce these. ${ }^{127}$ However, CRIs have no mandated procedure and it is argued that the nature of the power exercised and surrounding circumstances do not justify implying a duty to consult. ${ }^{128}$ It is unrealistic to expect NIWA to take submissions on how research

\footnotetext{
${ }^{123}$ Judicature Act 1908 High Court Rules cl 9.36.

${ }^{124}$ See Commerce Act 1986 s 77, Human Rights Act 1993 s 126 and Land Valuation Proceedings Act 1948 s 3.

${ }^{125}$ Jurs, above n 97 , at 87.

${ }^{126}$ Council of Civil Service Unions v Minister for the Civil Service [1984] 3 All ER 935.

${ }^{127}$ See New Zealand Pork Industry Board $v$ The Director-General of the Ministry of Agriculture and Forestry [2012] NZHC 888 and Walsh v Pharmaceutical Management Agency [2010] NZAR 101.

${ }^{128}$ Daganayasi v Minister of Immigration [1980] 2 NZLR 130 at 140. Walsh, above n 127, at [164].
} 
should be performed. ${ }^{129}$ Consulting non-experts would yield little benefit and expert opinion should be canvassed through a thorough literature review. Furthermore, Venning $\mathrm{J}$ reasons that the public may be affected by resulting government policies. To consult the public would not be feasible and would mean material would effectively be published before the official decision to publish was made. The scientific method also already provides for criticism of NIWA's approach. ${ }^{130}$ Wider consultation should only occur at the point that policy based on the research is formulated.

Error of fact claims are also problematic as they require serious errors regarding an incontrovertible fact which is central to the decision. ${ }^{131}$ Few incontrovertible facts exist in science, with uncertainty attached to virtually every result. Also, as NIWA's case demonstrates, it is practically impossible to demonstrate that it is an incontrovertible fact that a particular methodology should be used. Thus, even if available, the error of fact ground would rarely assist plaintiffs.

Venning J appeared to consider the "current state of knowledge" and "currently recognised scientific opinion" mandatory relevant considerations. ${ }^{132}$ However, given that in many fields there is much debate as to what the current state of science is, it would be inappropriate for generalist judges to determine what this entails.

Strong arguments exist that claiming the decision-maker was biased would rarely assist plaintiffs. The test for bias amongst judges is whether a "fair-minded lay observer would reasonably apprehend that the [decision-maker] might not bring an impartial mind" to the issue. ${ }^{133}$ Being in debt to or related to one of the parties is thus sufficient. ${ }^{134}$ However, research often relies on funding from organisations with vested interests. Furthermore, the process of formulating hypotheses arguably biases researchers towards a particular result. However, the scientific method is designed to assist the objective search for truth, regardless of researchers' backgrounds. Indeed, there are precautions in place to prevent scientists' expectations from influencing results, such as undertaking a double-blind trial, where neither the subject nor the investigator knows who is in the test and control groups. Additionally, many journals require authors to declare conflicting interests in their

\footnotetext{
${ }^{129}$ Walsh, above n 127 , at [163].

${ }^{130}$ See Part IIIC.

${ }^{131}$ Bryson v Three Foot Six Ltd [2005] 3 NZLR 721 as discussed in Joseph, above n 116, at 924 and 926.

132 NIWA's case, above $\mathrm{n}$ 1, at [82], [105] and [106].

${ }^{133}$ Saxmere Company Ltd v Wool Board Disestablishment Company Ltd (No 2) [2010] 1 NZLR 76 at [4].

${ }^{134}$ At [17]; Saxmere Company Ltd v Wool Board Disestablishment Company Ltd [2010] 1 NZLR 35 at [66].
} 
articles. ${ }^{135}$ A reasonable lay observer should understand this. Thus, scientists are only likely to be successfully accused of bias in the presence of corruption or fraud, which I argue below, is the only time that judicial review is justifiable.

Irrationality is also unlikely to yield results. No mitigating factors, as described in Wolf $v$ Minister of Immigration, apply so the threshold to demonstrate unreasonableness would be high. ${ }^{136}$ The Wednesbury test which requires a decision "so outrageous in its defiance of logic...that no sensible person...could have arrived at it" is falling from favour, but judges remain anxious not to usurp the decision-maker's role as finder of fact. ${ }^{137}$ Such high thresholds will never be satisfied when there is any scientific dispute on the matter, as there was in NIWA's case. Furthermore, to understand the differences between scientific methodologies often requires considerable training so the majority of "sensible" people could not be expected to distinguish between them.

The innominate or Guinness ground is perhaps the most far-reaching in judicial review, leaving much to the Court's discretion. It only requires that something has "gone wrong of a nature and degree which [requires] the intervention of the Court" ${ }^{138}$ Some judges consider it merely a repetition of the principle that courts are not confined to existing grounds of review; ${ }^{139}$ others view it as a distinct ground. ${ }^{140}$ However, in cases like NIWA's, the arguments made above might be rehearsed, demonstrating first that judicial intervention is not required, as either individuals' rights have not been affected or complainants have other forms of redress. ${ }^{141}$ Secondly, this part has raised serious questions about whether a dispute involving scientific research is of such a nature that the Court should intervene, due to issues surrounding the adversarial process and judicial expertise.

\footnotetext{
${ }^{135}$ See Jessica S Ancker and Annette Flanagin "A comparison of conflict of interest policies at peerreviewed journals in different scientific disciplines" (2007) 13 Sci Eng Ethics 147.

${ }^{136}$ Wolf v Minister of Immigration [2004] NZAR 414.

${ }^{137}$ Associated Provincial Picture Houses Ltd v Wednesbury Corporation [1947] 2 All ER 680 at 683; Joseph, above n 116, at 935-936.

${ }^{138} R v$ Panel on Take-overs and Mergers, ex parte Guinness plc [1990] 1 QB 146 (CA) at 160.

${ }^{139}$ Seataste Products Ltd v Director-General of Agriculture and Fisheries [1995] 2 NZLR 449 at 461.

${ }^{140}$ Roach v Kidd (High Court, Wellington, CP 715/91, 12 October 1992, McGechan J) as discussed in Laws of New Zealand Administrative Law (online ed) at [108].

${ }^{141}$ See Part III.
} 


\section{E Summary}

This part has demonstrated that strong arguments exist that the Court's personnel and processes are ill-equipped to resolve scientific issues. The adversarial system is unsuited to addressing polycentric decisions, whilst judges lack fundamental scientific knowledge and expert witnesses may not overcome this deficit. Even potential solutions such as appointing expert panels or reserving complex cases for scientifically-trained judges are problematic. Thus, powerful arguments exist that judicial review should be excluded completely through a finding of non-justiciability or a deferential standard applied (partial justiciability). Part V will explore why the latter is preferable.

\section{$V \quad$ Definitely deference: solutions to the problem of judicially reviewing scientific research.}

In this part, I examine how the problems with the adversarial system, judges' lack of training and expert witnesses explored above might be minimised. While non-justiciability may prevent judicial interference, it bucks the current trend towards increased scrutiny of public decision-makers and may allow CRIs acting fraudulently to escape consequences. However, something more than the deferential standard Venning $\mathrm{J}$ applied is needed as NIWA's case demonstrates that even judges endeavouring to avoid making scientific decisions may be unsuccessful. Furthermore, scientific advancement may slow if researchers must worry about judicial scrutiny. I propose an intermediate position, with judicial review reserved for instances of 'flagrant impropriety' in cases such as NIWA's.

\section{A Non-justiciability}

Whilst declaring scientific research matters to be non-justiciable would certainly protect the research process from judicial interference, it is problematic. Such a finding would run counter to New Zealand's trend towards increasingly intensive review. ${ }^{142}$ Courts are unwilling to leave public power unchecked, perhaps reflecting greater demand amongst ordinary New Zealanders for accountability in the public sector. ${ }^{143}$ Even those answerable to the public through elections may only escape review when addressing matters of high

\footnotetext{
142 Joseph, above n 116 , at 833 .

${ }^{143}$ At 833 .
} 
policy or national security. ${ }^{144}$ CRIs would appear out-of-place on the list of decisionmakers protected by non-justiciability.

Moreover, non-justiciability would protect any decision to publish by CRIs, even if it were fraudulent or corrupt. This is particularly troubling given taxpayer dollars are involved. Furthermore, aside from public and professional condemnation and employment consequences, New Zealand has no mechanism for addressing such behaviour. ${ }^{145}$ Indeed, only 11 countries worldwide do. ${ }^{146}$ Of these, the Danish Committee on Scientific Dishonesty is most comprehensive although limited to public health research. ${ }^{147}$ The committee comprises 14 members with "science expertise" but is chaired by a High Court judge. ${ }^{148}$ In addition to preventative work, it investigates falsification and distortion of results, plagiarism and inappropriate authorship credit. ${ }^{149}$ It is beyond the scope of this paper to determine the need for such a body in New Zealand. However, in its absence, courts should be able to sanction the worst offenders. Thus, decisions such as NIWA's should not be declared non-justiciable.

\section{B Deference or partial justiciability}

Whereas courts "have remained alert to situations of non-justiciability," the exercise of deference or its opposite, 'hard look review', is somewhat contentious in New Zealand. ${ }^{150}$ Deference or partial justiciability involves reviewing less intensively, for example by declining to examine certain matters or requiring a higher level of proof. ${ }^{151}$ Some judges, including Elias CJ, strongly oppose varying the intensity of review. ${ }^{152}$ Others have wavered, with Hammond J applying a 'hard look' in New Zealand Public Service

\footnotetext{
${ }^{144}$ Curtis $v$ Minister of Defence CA 289/10, 25 February 2002 at [28].

${ }^{145}$ Council of Science Editors "CSE's White Paper on Promoting Integrity in Scientific Journal Publications" $<$ www.councilscienceeditors.org $>$.

${ }^{146}$ Ibid.

${ }^{147}$ Hans Henrik Brydensholt "The Legal Basis for the Danish Committee on Scientific Dishonesty" (2000) 6 Science and Engineering Ethics 11.

${ }_{148}$ At 12.

149 At 22.

${ }^{150}$ Dean Knight “A Murky Methodology: Standards of Review in Administrative Law” (2008) 6 NZJPIL 117 at $134-135$ and 145 .

${ }^{151}$ Mark Elliott “Judicial Review's Scope, Foundations and Purposes: Joining the Dots” [2012] NZ L Rev 75 at 81 .

${ }^{152}$ Dean Knight "Mapping the Rainbow of Review: Recognising Variable Intensity" [2010] NZ L Rev 393 at 400-402.
} 
Association Inc v Hamilton City Council, before declaring such spectra unfeasible. ${ }^{153}$ Part of their concern is that deference suggests judicial obsequiousness or the Court's failure to properly fulfil its supervisory role. ${ }^{154}$ However, variable intensities of review have gained traction regarding the amelioration of Wednesbury unreasonableness. ${ }^{155}$ Authors and professionals have openly embraced the concept, with commentators concluding that unacknowledged deference is more widespread in New Zealand than commonly thought. ${ }^{156}$

Most common law jurisdictions utilise some form of deference. ${ }^{157}$ However, most literature on deference in science-related matters is, once again, US-based. US courts are at their "most deferential" when examining 'agency science', in an approach known as 'super-deference'. ${ }^{158}$ However, its effectiveness is questionable as decisions of organisations like the Environmental Protection Agency are frequently overturned, although this may reflect more on its policymaking than its research. ${ }^{159}$ Furthermore, even with deference, judges make mistakes when contemplating complex science. In Industrial Union Department v American Petroleum Institute for example, what the US Supreme Court found to constitute a "trivial risk" has been described as so plainly wrong that it would have been obvious to "anyone who has had Toxicology 101, even if they got a D in it". 160

\section{NIWA's case and the dangers of deference}

NIWA's case further illustrates the problems with deference. Despite stating that the Court should not determine matters of science, Venning $\mathrm{J}$ unintentionally decides scientific questions whilst unsuccessfully attempting to lower the intensity of review. He further fails to address issues surrounding the often-blurred boundary between science and fact,

\footnotetext{
${ }^{153}$ New Zealand Public Service Association Inc and Others v Hamilton City Council [1997] NZHC 30 at 33 and Lab Tests, above n 79, at [379]. For discussion, see Graham DS Taylor Judicial review: a New Zealand perspective ( $2^{\text {nd }}$ ed, LexisNexis, Wellington, 2010) at 89.

${ }_{154}$ Michael Taggart "Proportionality, Deference, Wednesbury" [2008] NZ L Rev 423 at 455.

${ }^{155}$ James Palmer and Kate Wevers "Judicial review in a commercial context" [2009] NZLJ 14 at15.

${ }^{156}$ Knight "Mapping the Rainbow", above n 152, at 411-412 and 429. Contrast with Edward Willis "Judicial review and deference" [2011] NZLJ 283.

${ }^{157}$ See Michael C Tolley "Judicial Review of Agency Interpretation of Statutes: Deference Doctrines in Comparative Perspective" (2003) 31 Policy Studies Journal 421.

${ }^{158}$ Baltimore Gas and Electric Co v National Resources Defense Council 462 US 87 (1983) at 103.

${ }^{159}$ Elliott, Raul, Pierce, McGarity and Wagner, above n 63, at 10129; Hammond Meazell "Super Deference", above $\mathrm{n} 61$, at 749 .

${ }^{160}$ Industrial Union Department v American Petroleum Institute 448 US 607 (1980); Elliott, Raul, Pierce, McGarity and Wagner, above n 63, at 10137.
} 
enabling future counsel to engage in the "science charade". Finally, even his deferential approach may lead to an ossification of research.

First, regarding inadvertent scientific decisions, Venning $\mathrm{J}$ is clear that the Court will not intervene in scientific matters. New Zealand Pork Industry Board v The Director-General of the Ministry of Agriculture and Forestry contains a similar statement that the Court will not determine whether institutions "got their science right."161 Venning $\mathrm{J}$ thus declares multiple issues to be matters of scientific debate and inappropriate for the Court to decide. These include whether NIWA properly accounted for sheltering of weather stations and whether the methodology used was open to it. ${ }^{162}$ However, in doing so, the judge is deciding for the scientific establishment that there remains a debate and no 'best' methodology exists for such cases. ${ }^{163}$ Here, this was probably true, with NIWA's expert citing journal articles describing multiple valid methodologies. ${ }^{164}$ However, judges may occasionally make the wrong decision and find there is on-going scientific debate when almost all experts are in agreement or vice versa.

Second, Venning $\mathrm{J}$ states that "less intensive review...is appropriate" but fails to implement a deferential standard. ${ }^{165}$ Both the judge and parties accept that NIWA must consider the "current state of knowledge". ${ }^{166}$ Thus, the Court must make a scientific judgment as to what this represents. The judge also makes no comment as to whether "officially recognised scientific opinion", the Trust's preferred standard, actually exists. He instead leaves it open for later courts to apply such a standard and mistakenly influence science. Furthermore, in saying that the Court will be "cautious" when addressing matters of science, Venning $\mathrm{J}$ does not rule out the Court openly intervening when it believes it may "definitively adjudicate on scientific opinions". 167

Additionally, as Ferrere notes, Venning J's attempt to introduce deference is ineffective. ${ }^{168}$ His requirement that the decision be "clearly wrong" before courts intervene actually equates to "a decision outside the permissible boundaries to the exercise of...discretion". 169

\footnotetext{
${ }^{161}$ New Zealand Pork Industry Board, above n 127, at [111].

${ }^{162}$ NIWA's case, above $\mathrm{n} 1$, at [80] and [172-173].

${ }^{163}$ Ferrere, above n 76, at 380.

${ }^{164}$ NIWA's case, above $\mathrm{n} 1$, at [80].

165 At [48].

${ }^{166}$ At [82].

${ }^{167}$ At [44] and [48].

${ }^{168}$ Ferrere, above $\mathrm{n} 76$, at 381 .

${ }^{169}$ Te Wini $v$ R [2011] NZCA 617 at [16], cited in Ferrere, above n 76, at 381.
} 
Since this is the normal standard applied in judicial review cases, Venning J's formulation allows later courts to scrutinise scientific research as they would any other decision. ${ }^{170}$

NIWA's case also highlights the blurred boundary between fact and science. Venning $\mathrm{J}$ will intervene in factual arguments, although the threshold for finding mistakes of fact is high. ${ }^{171}$ However, he will not (purposely) interfere in scientific debates, providing an incentive for plaintiffs to portray issues as mistakes of fact rather than scientific disagreements. Furthermore, judges may not always satisfactorily distinguish between factual and scientific issues, particularly as science is the search for facts, leading to a confusing overlap. If judges cannot reliably locate the boundary, the unwary may inadvertently judge science or fail to judge facts.

The Trust's complaint that the methodology used in NIWA's review was "flawed, unprecedented, outdated and unpublished" illustrates this difficulty. ${ }^{172}$ Whilst the judge considered this a scientific matter and thus deferred to NIWA, it might equally well be argued as a matter of fact as it could be determined whether a method is "unprecedented, outdated and unpublished" through examining scientific literature. Also treated as a scientific issue is the claim that NIWA did not account for non-climatic features which could have influenced results. ${ }^{173}$ However, NIWA could easily have demonstrated factually that it had identified relevant non-climatic influences and undertaken corrections (although the appropriateness of those corrections would be a matter of science).

The issue of counsel taking advantage of the difficulties inherent in distinguishing science from reviewable matters is known in US literature as the "science charade". ${ }^{174}$ As judges will defer to expert bodies on scientific matters, agencies creating science-based policy have allegedly portrayed "bad policy decisions as reasoned scientific analysis". 175 Meanwhile, plaintiffs try to argue scientific matters as policy decisions to encourage review. ${ }^{176}$ Such arguments may succeed improperly where judges lack scientific knowledge. Parties in the US already "race to the courthouse", hoping to be heard by

\footnotetext{
${ }^{170}$ Ferrere, above n 76 , at 381.

${ }^{171}$ See Part IVD.

${ }^{172}$ NIWA's case, above $\mathrm{n} 1$, at [152].

${ }^{173}$ At [165].

${ }^{174}$ Clark, above n 60, at 346.

${ }^{175}$ At 342 .

${ }^{176}$ At 346 .
} 
particular judges who will be more or less willing to involve themselves in issues of science. $^{177}$

Furthermore, scientists may be reticent to publish knowing that judges may scrutinise their work, particularly if their results are controversial. The mere existence of a court case may impact their reputations and employment prospects, especially given the cost to employers. Indeed, NIWA spent over $\$ 100,000$ defending itself against the Trust's allegations, although it was later awarded costs. ${ }^{178}$ The resultant unwillingness to publish would be problematic as publishing and garnering critique from peers is vital to the scientific method. Alternatively, scientists may expend excessive time and resources gathering more data and conducting multiple analyses to ensure they will not be criticised by the Court. Plaintiffs also favour "blunderbuss attacks", with counsel criticising as many aspects of the science as possible, hoping that one argument at least will be accepted. ${ }^{179}$ Such tactics potentially distort the focus of science by forcing scientists to consider and address any minor point which might be scrutinised in court. ${ }^{180}$

\section{$D$ The flagrant impropriety standard}

This paper has demonstrated that denying review based on non-justiciability leaves the system open to abuse by scientists. ${ }^{181}$ However, Venning J's model of deference offers the research process too little protection, ignoring the inadequacies of the court process in relation to scientific matters. The solution therefore appears to lie between the two, with what Knight calls "flagrant impropriety". ${ }^{182}$ This standard is typified by the Privy Council's determination in Mercury Energy Ltd v Electricity Corporation of New Zealand Ltd. ${ }^{183}$ Instead of plaintiffs having access to all the grounds of review, the Court would only intercede in SOEs" commercial activities in cases of "fraud, corruption or bad faith."

\footnotetext{
${ }^{177}$ Thomas O McGarity “Judicial Review of Scientific Rulemaking” (1984) 9 Science, Technology \& Human Values 97 at 103.

${ }^{178}$ Trevor Quinn "Climate sceptics fail in NIWA case" Dominion Post (online ed, Wellington, 7 September 2012).

${ }^{179}$ Hammond Meazell "Super Deference", above n 61, at 750; Thomas O McGarity "Daubert and the Proper Role for the Courts in Health, Safety and Environmental Regulation" (2005) 95 Am J Public Health 92 at S96.

${ }^{180}$ McGarity “Daubert”, above n 179, at S97.

${ }^{181}$ See Part IVD.

182 Knight "Murky Methodology", above n 150, at 136.

${ }^{183}$ Mercury Energy, above n 5.

${ }^{184}$ At 391.
} 
Venning J expressly rejected this standard in NIWA's case, reasoning that plaintiffs may challenge SOEs' decisions in private law but have no such recourse with CRIs. However, as demonstrated in Part III, other options are available and since individuals' rights will only be impacted when a resulting policy decision is implemented, only at this later stage should intensive judicial review be conducted. It is arguable that Mercury Energy may be distinguished as SOEs operate in the private commercial sphere, whilst NIWA is entirely public-focused. However, SOEs make decisions which would otherwise be private, but because they are themselves public entities, these decisions are within the Court's jurisdiction. NIWA is the same; as demonstrated earlier, its decisions had no "real practical" public consequences. ${ }^{185}$ Only NIWA's position as a public body justified a finding of 'publicness'. Furthermore, universities conducting similar work might be assisted by "the freedom...to engage in research" enshrined in the Education Act 1989, as publishing is integral to the research process. ${ }^{186}$ New Zealand has witnessed a trend towards decreasing judicial intervention in the market, with judges viewing commerce as sacrosanct. ${ }^{187}$ This does not mean that commercial decisions alone should be afforded protection. Science also makes invaluable contributions to society.

Restricting review to cases of flagrant impropriety surmounts the arguments raised in the three parts above. It acknowledges the improbability of individuals being harmed by decisions such as NIWA's. However, it provides a legal remedy should scientists behave improperly. It also recognises the risk that judges might inadvertently make decisions of science, which would be particularly harmful given the unsuitability of the adversarial system and indeed, judges themselves to determining such issues. Instead, it places the Court squarely within its usual range of operations, examining the facts to determine whether fraud has occurred. In doing so, it reassures the public that CRIs acting inappropriately will be held accountable.

\section{E Summary}

Having examined the arguments for both non- and partial justiciability, I conclude that "fraud, corruption or bad faith" is the optimal standard of deference when reviewing decisions such as NIWA's. A finding of non-justiciability would give scientists a freedom

\footnotetext{
${ }^{185}$ See Part III; Peters v Davison, above n 42, at 188.

${ }^{186}$ Education Act 1989 s 161(2)(b).

${ }^{187}$ See Palmer and Wevers, above n 155.
} 
to act improperly that is almost unparalleled in the public sphere. However, Venning J's standard of deference allows judges to unintentionally determine scientific issues. In attempting to lower the intensity of review, he in fact allowed later courts to be anything but deferential. His decision also ignored the significant problem of the blurred boundary between fact and science which may allow unwary judges to decide matters of science. Scientific advancement might be delayed as scientists endeavour to ensure their decisions are above reproach, or forego publishing entirely. Thus, review should be restricted to cases of flagrant impropriety.

\section{Conclusion}

This paper proposed an alternative standard of judicial review in cases of scientific research to that adopted by Venning $\mathrm{J}$ in NIWA's case. Whilst the judge was right to find NIWA's decisions to be within the Court's jurisdiction, its decision to publish did not directly impact individuals' rights. A finding that research could impact reputations presumes that the public would be willing to accept the findings of a single piece of research, despite knowing that science is not infallible. The absence of judicial review would also not leave plaintiffs without redress as they may seek review of any policy decision based upon the scientific research. This already occurs in the European Community Courts. Furthermore, if plaintiffs have a valid scientific point, they could ask a reputable scientist to write a paper and have it published in a credible journal, and if the scientific community agrees, the initial conclusion would be discredited. However, Venning J was still justified in determining that NIWA's decisions were within the Court's public law jurisdiction as courts do not apply a purely functional approach. Thus, NIWA's nature as a public institution meant that its decisions may be considered public.

However, the adversarial system may not appropriately address scientific issues given its incompatibility with the scientific method. Expert witnesses appearing in court tend to be those outside the mainstream of scientific opinion, selected primarily for their ability to support the client's arguments. Moreover, judges lack the expertise to become involved in scientific decisions, with US studies revealing very low scientific proficiency in their judiciary.

If these problems were remedied by finding NIWA's decisions to be non-justiciable, scientists might escape scrutiny when acting fraudulently or in bad faith. Thus, partial 
justiciability, or deference, is preferable; however, Venning J's formulation enables inexpert judges to determine matters of science. The judge himself inadvertently draws conclusions as to science, and his attempt at deference is unsuccessful as the standard he sets is no different from usual. Furthermore, scientific judgments are necessary to determine whether the required "current state of knowledge" has been considered. There is also a risk that counsel may encourage the confusion of fact and science, as Venning $J$ is prepared to review matters of fact but will not intervene in scientific disputes. In addition, should scientists become concerned that judges lacking scientific expertise will criticise their work, they may spend excessive time and resources ensuring their research is above reproach. These issues will not be resolved by a low standard of deference. Instead, decisions regarding CRIs' research should be reviewed only in cases of flagrant impropriety or "fraud, corruption or bad faith". This standard protects the research process from non-scientist judges but allows courts to intervene when scientists have acted reprehensibly.

Thus, NIWA's decisions should not have been judicially reviewed as they were. Whilst they fall under the Court's public law jurisdiction, the nature of the Court's processes makes it unsuited to determining such issues, requiring an extremely high level of deference. Instead, the Trust should have utilised non-legal methods or waited and sought judicial review of a resulting policy decision. As to whether these findings might be applied to other cases involving complex scientific evidence, we must conclude, like every good science paper, that more research is needed. 


\section{Bibliography}

I. New Zealand Case Law

Agrotain International LLC v Fertiliser Quality Council Inc HC Wellington CIV 2009485-1855, 17 December 2009.

Auckland Electric Power Board v Electricity Corporation of New Zealand CA 45/93, 8 September 1993.

Council of Civil Service Unions v Minister for the Civil Service [1984] 3 All ER 935.

Cowl v Plymouth City Council [2002] 1 W.L.R. 803.

Curtis v Minister of Defence CA 289/10, 25 February 2002.

Daganayasi v Minister of Immigration [1980] 2 NZLR 130.

Finnigan v New Zealand Rugby Football Union Inc (No 2) [1985] 2 NZLR 181.

Lab Tests Auckland Ltdv Auckland District Health Board [2008] NZCA 385.

Mercury Energy Ltd v Electricity Corporation of New Zealand Ltd [1994] 2 NZLR 385.

New Zealand Climate Science Education Trust v National Institute of Water and Atmospheric Research Ltd [2012] 1 NZLR 75.

New Zealand Pork Industry Board $v$ The Director-General of the Ministry of Agriculture and Forestry [2012] NZHC 888.

New Zealand Public Service Association Inc and Others v Hamilton City Council [1997] NZHC 30.

Peters v Davison [1999] 2 NZLR 164.

$R v$ Carter (2005) 22 CRNZ 476.

$R v$ Somerset County Council ex p Dixon [1997] COD 323.

Reckitt and Coleman (New Zealand) Ltd v Pharmaceutical Management Agency Ltd [1997] NZAR 464.

Royal Australasian College of Surgeons v Phipps [1998] 3 NZLR 1.

Saxmere Company Ltd v Wool Board Disestablishment Company Ltd [2010] 1 NZLR 35.

Saxmere Company Ltd v Wool Board Disestablishment Company Ltd (No 2) [2010] 1

NZLR 76.

Seataste Products Ltd v Director-General of Agriculture and Fisheries [1995] 2 NZLR 449 . 
University of Auckland v Tertiary Education Commission [2004] 2 NZLR 668.

Waitakere City Council v Waitemata Electricity Shareholders Society Inc [1996] 2 NZLR 735 .

Walsh v Pharmaceutical Management Agency [2010] NZAR 101.

Wolf v Minister of Immigration [2004] NZAR 414.

II. New Zealand Statutes

Commerce Act 1986.

Crown Research Institutes Act 1992.

Education Act 1989.

Evidence Act 2006.

Human Rights Act 1993.

Judicature Act 1908 .

Judicature Amendment Act 1972.

Land Valuation Proceedings Act 1948.

\section{Overseas Case Law}

Joined Cases T-75/00, T-76/00, T-83/00, T-84/00, T-85/00, T132/00, T-137/00, T-141/00 Artegodan GmbH e.a. v Commission [2002] ECR 4945.

Baltimore Gas and Electric Co v National Resources Defense Council 462 US 87 (1983).

Belize Alliance of Conservation Non-Governmental Organizations $v$ The Department of the Environment and Belize Electric Company Ltd [2003] UKPC 47.

Daubert v Merrell Dow Pharmaceuticals Inc [1993] US SC 92.

Case T-326/99 Nany Fern Olivieri v Commission and European Agency for the Evaluation of Medicinal Products [2003] ECR II-06053.

$R v$ Panel on Take-overs and Mergers, ex parte Datafin plc [1987] 1 All ER 564.

$R v$ Panel on Take-overs and Mergers, ex parte Guinness plc [1990] 1 QB 146 (CA).

Vernon v Bosley (No 2) [1997] 1 All ER 614 (CA). 
Associated Provincial Picture Houses Ltd v Wednesbury Corporation [1947] 2 All ER 680 .

\section{New Zealand Journal Articles}

Jenny Cassie and Dean Knight "The Scope of Judicial Review: Who and what may be reviewed" (paper presented to New Zealand Law Society Administrative Law Conference, August 2008) 63.

Malcolm Downden "Has climate change litigation become more difficult?" [2010] 160 NLJ 171.

Mark Elliott “Judicial Review's Scope, Foundations and Purposes: Joining the Dots" [2012] NZ L Rev 75.

Marcelo Rodriguez Ferrere "Judicial review of scientific findings" [2012] NZLJ 380.

Dean Knight "Mapping the Rainbow of Review: Recognising Variable Intensity” [2010] NZ L Rev 393.

Dean Knight "A Murky Methodology: Standards of Review in Administrative Law" (2008) 6 NZJPIL 117.

Dean R Knight "Dunne v Canwest TVWorks Ltd: Enhancing or Undermining the Democratic and Constitutional Balance?” (2005) 21 NZULR 712.

James Palmer and Kate Wevers "Judicial review in a commercial context" [2009] NZLJ 14.

Michael Taggart "Proportionality, Deference, Wednesbury” [2008] NZLR 423.

Edward Willis "Judicial review and deference" [2011] NZLJ 283.

\section{Overseas Journal Articles}

Jessica S Ancker and Annette Flanagin "A comparison of conflict of interest policies at peer-reviewed journals in different scientific disciplines" (2007) 13 Sci Eng Ethics 147.

David E Bernstein "Expert Witnesses, Adversarial Bias, and the (Partial) Failure of the Daubert Revolution" [2008] 93 Iowa Law Review 101

Hans Henrik Brydensholt "The Legal Basis for the Danish Committee on Scientific Dishonesty" (2000) 6 Science and Engineering Ethics 11.

Kristin Carden "Bridging the Divide: the Role of Science in Species Conservation Law" (2006) 30 Harv Envtl L Rev 165. 
Edward K Cheng "Independent Judicial Research in the Daubert Age" (2007) 56 Duke Law Journal 1263.

Sara A Clark "Taking a Hard Look at Agency Science: Can the Courts Ever Succeed?" (2009) 36 Ecology LQ 317.

Kenneth Culp Davis "Ripeness of Governmental Action for Judicial Review" (1955) 68 Harv L Rev 1122.

Holly Doremus "The Purposes, Effects and Future of the Endangered Species Act's Best Available Science Mandate" (2004) 34 Envtl L 397.

E Donald Elliott, Alan Charles Raul, Richard J Pierce Jr., Thomas O McGarity \& Wendy E Wagner "Science, Agencies, and the Courts: Is Three a Crowd?” (2001) 31 ELR 10125.

Chris Finn “The Justiciability of Administrative Decisions: A Redundant Concept?” 30 FLR 240.

Chris Finn "The concept of 'justiciability' in administrative law" in Matthew Groves and H P Lee, Australian Administrative Law: Fundamentals, principles and doctrines (Cambridge University Press, Cambridge, 2007) 143.

Patrick A Fuller "How Peer Review of Agency Science Can Help Rulemaking: Enhancing Judicial Deference at the Frontiers of Knowledge" (2007) 75 Geo Wash L Rev 931.

Sophia I Gatowski, Shirley A Dobbin, James T Richardson, Gerald P Ginsburg, Mara L Marino and Veronica Dahir "Asking the Gatekeepers: A National Survey of Judges on Judging Expert Evidence in a Post-Daubert World" (2001) 25 Law and Human Behaviour 433.

B V Harris "Judicial Review, Justiciability and the Prerogative of Mercy" (2003) 63 CLJ 631.

Oliver Hartmann "The (Dis) Entanglement of Law and Science: Judicial Review of Science-Based Measures by EC Courts" (LLM Dissertation, University of Maastricht, 2008).

Matthijs Hisschemöller and Rob Hoppe "Coping with Intractable Controversies: The Case for Problem Structuring in Policy Design and Analysis" (1996) 8 Knowledge and Policy 40.

Andrew Jurs "Judicial Analysis of Complex \& Cutting-edge Science in the Daubert Era: Epidemiologic Risk Assessment as a Test Case for Reform Strategies” (2009) 42 Conn L Rev 49.

Jan de Keijser and Henk Elffers "Understanding of forensic expert reports by judges, defense lawyers and forensic professionals” (2010) 18 Psychology, Crime \& Law 191. 
Graham Knight and Josh Greenberg "Talk of the Enemy: Adversarial Framing and Climate Change Discourse” (2011) 10 Social Movement Studies: Journal of Social, Cultural and Political Protest 323.

Thomas O McGarity “Judicial Review of Scientific Rulemaking” (1984) 9 Science, Technology \& Human Values 97.

Thomas O McGarity "Daubert and the Proper Role for the Courts in Health, Safety and Environmental Regulation” (2005) 95 Am J Public Health 92.

Emily Hammond Meazell "Super Deference, the Science Obsession and Judicial Review as Translation of Agency Science” (2011) 109 Michigan Law Review 733.

Emily Hammond Meazell "Scientific Avoidance: Toward More Principled Judicial Review of Legislative Science” (2009) 84 Indiana Law Journal 240.

Greg O'Hare "Reviewing the Uncertainties in Climate Change Science" (2000) 32 Area 357.

Connie P Ozawa "Science and Intractable Conflict" (2006) 24 Conflict Resolution Quarterly 197.

\section{Books}

Peter Cane Administrative Law (5 ${ }^{\text {th }}$ ed, Oxford University Press, Oxford, 2011).

Jake Chapman, Charlie Edwards and Simon Hampson Connecting the Dots (Demos, London, 2009).

Emily Henderson and Fred Seymour Expert Witnesses Under Examination in the New Zealand Criminal and Family Courts (New Zealand Law Foundation, Auckland, 2013).

Philip A Joseph Constitutional \& administrative law in New Zealand ( $3^{\text {rd }}$ ed, Thomson Brookers, Wellington, 2007).

NIWA Report on the Review of NIWA's 'Seven-Station' Temperature Series NIWA Information Series No. 78 (NIWA, Wellington, 2010).

Graham DS Taylor Judicial review: a New Zealand perspective ( $2^{\text {nd }}$ ed, LexisNexis, Wellington, 2010).

VII. Other

Council of Science Editors "CSE's White Paper on Promoting Integrity in Scientific Journal Publications" <www.councilscienceeditors.org $>$. 
Ministry of Business, Innovation \& Employment "Crown research institutes" (1 February 2013) <www.msi.govt.nz>.

Ministry for Business, Innovation and Employment "Senior leadership" (30 January 2013) $<$ www.mbie.govt.nz>.

Ministry for the Environment "Leadership Team" (25 January 2013) <www.mfe.govt.nz>. Ministry of Health “Executive Leadership Team” (21 September 2012)

$<$ www.health.govt.nz $>$.

Ministry for Primary Industries "Senior Leadership Team” (25 July 2013)

$<$ www.mpi.govt.nz>.

NIWA “Seven-station” series temperature data" <www.niwa.co.nz>.

NIWA “Our Science" <www.niwa.co.nz>.

Trevor Quinn "Climate sceptics fail in NIWA case" Dominion Post (online ed, Wellington, 7 September 2012).

James Renwick "Leading Climate Scientists Welcome Judge's Decision" (press release, 7 September 2012).

\section{Word count}

The text of this paper (excluding table of contents, footnotes, and bibliography) comprises approximately 8,000 words. 